\title{
WHAT IS ESSENTIAL IS INVISIBLE TO EYE: A DIDACTIC RESEARCH ON MICROBIOLOGY AND HEALTH EDUCATION IN THIRD GRADE OF PRIMARY SCHOOL THROUGH PLAYING AND LABORATORY APPROACH
}

\author{
Beatrice Massaro ${ }^{1}$, Marta Bellio ${ }^{2}$, Elisabetta Piva ${ }^{3}$, Sophia Schumann ${ }^{4}$, Paola Irato ${ }^{5}$, \\ Gianfranco Santovito ${ }^{6 *}$ \\ ${ }^{1}$ Dr, University of Padova, ITALY, beatrice.massaro@studenti.unipd.it \\ ${ }^{2}$ Dr, University of Padova, ITALY, marta.bellio@ unipd.it \\ ${ }^{3} \mathrm{Dr}$, University of Padova, ITALY, elisabetta.piva.2@studenti.unipd.it \\ ${ }^{4} \mathrm{Dr}$, University of Padova, ITALY, Sophia.shumann@studenti.unipd.it \\ ${ }^{5}$ Dr, University of Padova, ITALY, paola.irato@unipd.it \\ ${ }^{6}$ Prof, University of Padova, ITALY, gianfranco.santovito@studenti.unipd.it \\ ${ }^{*}$ Corresponding Author
}

\begin{abstract}
The study aimed at investigating the effectiveness of teaching Biology at primary school by playing and using a laboratory approach, in a limited-resources learning environment with additional restrictive rules due to the current pandemic emergency. It also investigated the possibility of dealing with Microbiology topics, such as microorganisms and their role in human life. These topics are traditionally not taught at primary school, particularly at third grade.

The research process was based on the hypothesis that the adopted methodology may be useful to foster the active co-construction of knowledge and to increase the pleasure in learning. It makes pupils the main subjects of their learning process, with positive impacts on interest towards Science and on building an active citizenship.

First of all, an online survey about Science, Microbiology and Health Education teaching was supplied. The sample consisted of teachers and parents of the school in which the research was carried out and of the Venice province. Then, a test about foreknowledge and interest towards Science and microorganisms was submitted to students. Outcomes were analysed in order to identify the experimental and the control group among two primary school third grade classes in a town of the Venice province.

The experimental group was tested with activities characterized by the application of the scientific method and the learner-centred approach, engaging from an emotional, sensory and playful point of view. The control group was, instead, tested with a traditional and teacher-centred approach.

Tests and ongoing observation data supported the possibility of teaching Microbiology topics using both the approaches. The laboratory approach was more successful than the traditional one in knowledge acquisition but that is a subtle difference. The effectiveness was more significant in: developing interest towards Science and microorganisms, implementing inclusion and enhancing participation, promoting pleasure in learning and limiting negative feelings linked to the topics.
\end{abstract}

Keywords: health education, laboratory approach, microorganisms, playful approach, scientific method. 


\section{INTRODUCTION}

\subsection{Biology and Microbiology at school}

It's worth teaching Biology both for informative and formative objectives with regards, for example, to the individual health or to the development of an active citizenship. In addition, Biology can provide food for thought with children and can be adapted to make everyone included (CAST, 2011 ; Longo, 2014; Padoa Schioppa, 2014; ONU, 2015). Even though Biology is part of teaching curricula, a lack of scientific culture is increasingly widespread among society. Lack of scientific culture means difficulties in searching needed information and low interest in doing it. It also involves a mistrust towards Science and a perception of phenomena and reality often influenced by emotions (Padoa Schioppa, 2014, Santovito, 2015; Pluviano and Della Sala, 2020).

Furthermore, Microbiology is traditionally absent in primary teaching or has a marginal role, in particular in the earliest grades (MIUR, 2012; Santovito, 2015). However, there are many connections between this discipline and the real life. Microorganisms play a fundamental role in human life: from the food industry and the interaction with the human body or with the ecosystems, to diseases and pharmaceutical industry, etc. In the current context, characterized by the Sars-Cov-2 pandemic and other critical situations such as the microorganisms medicine resistance or the raising vaccination hesitancy, Microbiology can offer lots of opportunities (Tortora et al., 2008; Curtis and Barnes, 2009; Strategic Advisory Group of Experts on Immunization, 2014; Sheldrake, 2020). The reason of the lack of scientific culture could be sought in the poor interest of students and teachers. The right methodological approach may be the key to promote interest (Gainotti and Modelli, 2008; Santovito, 2015). The active and the laboratory approach, well integrated with frontal lessons, can reduce the distance between students and Science (Padoa Schioppa, 2014). Playing, dramatization, storytelling, discussion group, experimental activities, group works, problem posing and problem solving are some of the techniques which put students at the centre of the learning process (Padoa Schioppa, 2014; Nistor et al., 2018) and engage them cognitively and emotionally (Longo, 2014).

With the purpose of creating an interactive learning environment it's important to begin from pupils' foreknowledge or wrong knowledge based on everyday experiences (Danesi, 2006). Laboratory experiences allow to see, to touch and to act on the reality. Nevertheless, the kind of laboratory experience this study considers is not a mere implementation of structured experiments but gives students the possibility of testing themselves with the following activities: observation, question posing, development of hypothesis and tests to verify them, data collection and, above all, mistakes (Longo, 2014). It implies the application of the scientific method, both the logical-deductive method (Mayr, 1982) and the comparative-observational method. This approach also promotes the development of scientific mindset, critical sensibility and curiosity (Santovito, 2015). It's important for future scientists (Nistor et al., 2018) but even, in everyday-life, to interpret the huge amount of data and information which people in the contemporary society are surrounded by (Merkel, 2016; MIUR, 1918).

Health Education and hygienic rules are, formally and informally, part of the teaching curricula from the earliest grades. They are usually taught through role model strategies, routines and everyday recommendations but in a superficial way. Microbiology and Immunology are rarely involved and lessons do not deal with the real meaning of hygienic rules. We also think that the importance of microorganisms in human life or in the ecosystems is often forgotten even if it could strengthen the interest and the fascination for Science. For children, invisible beings can be fascinating and exciting like a magic and, above all, invisible does not mean incomprehensible for young minds. Using the right method and the right level of topic arrangement, everything could be taught (Vygotskij, 1934; Padoa Schioppa, 2014, Santovito, 2015; Pluviano and Della Sala, 2020).

\subsection{Purpose of the research}

The first purpose of this study was to investigate the effectiveness of playing and laboratory approach in teaching Biology at primary school, in a limited-resources learning environment with additional restrictive rules due to the current pandemic emergency. The effectiveness of the methodology, compared with a traditional one, was particularly meant with reference to the active knowledge co-construction (Pontecorvo et al., 2004; Nigris, 2005; Messina and De Rossi, 2015), to the pleasure in learning and to the interest in Science. The second purpose was to verify if Microbiology topics, such as microorganisms and their role in human life, can be taught at primary school, particularly at third grade. 


\section{METHODOLOGY}

\subsection{Background}

Before implementing the experimental activities, an online survey about Science, Microbiology and Health Education teaching was administered. The questionnaire was targeted at teachers and parents of the school where the study was carried out and of the Venice province. The survey was useful to better understand the background in which the research took place. The main investigated issues among teachers were: interest, adopted didactic approach and methodologies, tools and topics. Parents, instead, were asked to express their opinion about specific topics, about the importance of Science in their children's life and about approaches and methodologies more effective to understand and foster the interest.

An initial test about the level of foreknowledge and interest was submitted to the students of the two third grade classes of a primary school located in a town of Venice province. The test was designed in order to draw out what pupils already knew, or did not know, and to identify the experimental and the control group. The structured and unstructured questions related to Science, microorganisms, diseases, hygienic rules, antibiotics and vaccines.

\subsection{Learning objectives of the experimentation}

Table 1 summarizes the learning objectives pursued through the proposed activities.

Table 1. Learning objectives.

\begin{tabular}{|l||l|}
\hline $\begin{array}{l}\text { Cognitive } \\
\text { objectives } \\
\text { in terms of } \\
\text { knowledge } \\
\text { and skills) }\end{array}$ & $\begin{array}{l}\text { - to know characteristics of virus, bacteria and fungi and their role in human life; } \\
\text { - to understand the body defence system functioning even related with vaccines and } \\
\text { antibiotics; } \\
\text { - to acquire the main hygienic rules; } \\
\text { - to collect, order, analyze and interpret data; } \\
\text { - to observe and describe phenomena in real life. }\end{array}$ \\
\hline \hline $\begin{array}{l}\text { Behavioral } \\
\text { and attitude } \\
\text { objectives }\end{array}$ & $\begin{array}{l}\text { - to take care of their own and other people's health; } \\
\text { - to stimulate interest towards Science, Biology and Microbiology; } \\
\text { - to enhance the pupils' curiosity towards what happens around them, the habit of } \\
\text { posing questions and seeking answers through a scientific approach. }\end{array}$ \\
\hline
\end{tabular}

In a competence development perspective, learning objectives refer to three levels: knowledge, skills and attitudes (Castoldi, 2016).

\subsection{Method and Didactic Tool}

We proposed, to the experimental group, activities characterized by the application of the scientific method and the learner-centred approach (MIUR, 2012; Santovito, 2015). Playful and experimental activities were integrated with frontal lessons and knowledge formalization moments (Messina and De Rossi, 2015), paying attention to structure a learning environment that was engaging from an emotional, sensory and playful point of view (Padoa Schioppa, 2014).

The first step consisted of exploiting the foreknowledge collected through the initial test or by questioning children while discussing. In this way, it was possible to build new knowledge on the previous one and to review misconceptions. Posing questions and stimulating children to do the same was the guideline during the entire path. It was fundamental to implement the scientific method. Observation was made by using as many senses as possible. Not only sight but also smell and touch in order to make the experience complete, engaging and fixed in the mind. Observation was often supported by collecting data and by drawing in order to train and to trigger the hand-brain-eye connection (Longo, 2014; Santovito, 2015).

When possible, role playing, games and team activities were proposed. In this way students could think about and reason on important phenomena even if they couldn't directly observe them. Furthermore, it was a way to negotiate knowledge and contents among the group (Pontecorvo et al., 2004) and to learn having fun, soothing anxiety, without being aware of the effort. The interest in Science and microorganisms can be 
enhanced because linked to positive feelings and thanks to the feeling of playing an active role in his/her learning process (Minelle et al., 2016). In addition, other strategies were adopted. For instance, making explicit connection between studied topics and real life was useful to activate the transfer (Semeraro, 2009; Kaminskeet al., 2020). Whereas reading aloud allowed to engage children as only a story can do by arousing emotions and wonder. Drawing up a wide and heterogeneous range of strategies was aimed at reaching out the several pupils' cognitive and learning structures by respecting the inclusion perspective (Tomlinson, 2006; CAST, 2011).

In line with the frequent lack of resources in the schools, information technologies like LIM or sophisticated scientific tools like microscopes, weren't used. Definitely, the possibility of using it would have been interesting e would have enriched the experience, but one of the aims of the research was exactly to demonstrate that this lack is not an obstacle to effectively teach Microbiology. In addition to the common stationary that is in every school, the used material was easy to find out and not expensive, such as beer yeast, flour, plastic cups, bread or Petri dishes. As support to the proposed activities, didactic materials were specifically made. Other ones were downloaded from eBug website and modified in order to make them suitable to the pupils' needs and age or to the objectives we wanted to get. eBug is an online source the Health Protection Agency and the Public Health Department have made available for UK teachers in order to strengthen the interest towards Science and to enrich teaching curricula with health and microorganisms topics. The project is targeted at pupils from the fourth grade of primary school to the secondary school. Nevertheless, if edited in the right way it may be an interesting and reliable source for teachers, especially because these topics aren't usually included on the textbooks (Public Health England, 2020).

\subsection{Activities}

Five lessons, each lasting two hours, were held in both of the classes in February and March 2021. After the lessons, the groups did a final test, a self-assessment and a satisfaction survey. The purpose was to compare initial and final results between the two classes. The experimental group's learning process was based on methodologies and approaches described above, while the control group was tested with a traditional and teacher-centred approach. The tenured teacher conduced lessons based on discussing, reading and studying supplied materials or on watching videos.

Table 2. Activities.

\begin{tabular}{|c|c|c|}
\hline & Experimental group & Control group \\
\hline $\begin{array}{l}\text { First lesson: } \\
\text { microorganisms } \\
\text { with particular } \\
\text { focus on virus, } \\
\text { bacteria and } \\
\text { fungi. }\end{array}$ & $\begin{array}{l}\text { - Sorted transcription of the questionnaire answers } \\
\text { with guiding questions (Wiggins and Mc Thighe, } \\
\text { 2004): What are they? How are they? What do } \\
\text { they? Where are they? } \\
\text { - Reading aloud of the illustrated book "Tiny. The } \\
\text { invisible world of microbes" (Davies and Sutton, } \\
\text { 2015). During the reading, pupils had to figure out } \\
\text { the wrong initial hypothesis and then, led by the } \\
\text { teacher, had to correct them in order to build a } \\
\text { definition of microorganisms. } \\
\text { - Compared presentation of the main } \\
\text { characteristics and shapes of virus, bacteria and } \\
\text { fungi by using didactic sheets, poster, images and } \\
\text { guessing games. } \\
\text { - Realization of a clay microbe as homework. }\end{array}$ & $\begin{array}{l}\text { - Moment dedicated to } \\
\text { bring out foreknowledge } \\
\text { by questioning, drawing } \\
\text { and conversation. } \\
\text { - Reading and } \\
\text { comprehension of } \\
\text { materials about virus and } \\
\text { bacteria accompanied by } \\
\text { stimulating questions. }\end{array}$ \\
\hline $\begin{array}{l}\text { Second lesson: } \\
\text { beneficial } \\
\text { microorganisms, } \\
\text { mould, yeast, } \\
\text { fermentation. }\end{array}$ & $\begin{array}{l}\text { - Observation of a slice of bread characterized by } \\
\text { many air bubbles while asking, at the same time, } \\
\text { "Why has bread bubbles?". } \\
\text { - Formulation of the hypothesis starting from pupils' } \\
\text { foreknowledge and previous experiences emerged } \\
\text { while discussing. }\end{array}$ & $\begin{array}{l}\text { - Revision of the contents. } \\
\text { - Reading and } \\
\text { comprehension of } \\
\text { materials about fungi } \\
\text { accompanied by } \\
\text { stimulating questions. }\end{array}$ \\
\hline
\end{tabular}




\begin{tabular}{|c|c|c|}
\hline & $\begin{array}{l}\text { - Implementation of the experiment aimed at testing } \\
\text { the hypothesis (dough put into four plastic cups } \\
\text { signing the initial levels). } \\
\text { - Data gathering on a structured sheet while } \\
\text { observing what happens to each cup with } \\
\text { differently composed dough in terms of sugar, hot } \\
\text { water and yeast (Fig. 1A). } \\
\text { - Analysis of the dough measures gathered by } \\
\text { reasoning on the initial hypothesis thanks to } \\
\text { guiding questions. } \\
\text { - Formalization of the new discovered knowledge } \\
\text { on a chart. } \\
\text { - Multi-sensorial observation of Gorgonzola cheese } \\
\text { and of a decaying orange mould. }\end{array}$ & $\begin{array}{l}\text { - Observation of an } \\
\text { orange mould. } \\
\text { - Explanation about the } \\
\text { usefulness of fungi } \\
\text { kingdom and bacteria in } \\
\text { human life. } \\
\text { - Watching videos about } \\
\text { microorganisms on hands } \\
\text { and about the yogurt } \\
\text { production. }\end{array}$ \\
\hline $\begin{array}{l}\text { Third lesson: } \\
\text { harmful } \\
\text { microorganisms } \\
\text { and hand } \\
\text { hygiene. }\end{array}$ & $\begin{array}{l}\text { - Discussion about some images to understand in } \\
\text { what situations diseases are caused by microbes } \\
\text { and when they aren't. } \\
\text { - Crossword about diseases and infections. } \\
\text { - Problem posing: "Are there more microbes on } \\
\text { dirty hands or on clean hands?" and "When are } \\
\text { hands really clean?". } \\
\text { - Formulation of a hypothesis. } \\
\text { - Implementation of the experiment aimed at testing } \\
\text { the hypothesis (culture of hand microorganisms on } \\
\text { Petri dishes). } \\
\text { - Observation and data gathering on a structured } \\
\text { sheet. Groups, composed of three children, had to } \\
\text { observe, after } 2 \text { and } 7 \text { days, dishes touched by } \\
\text { dirty hands, by hands washed using water only and } \\
\text { by hands washed using water and soap (Fig. } 1 \text { A). }\end{array}$ & $\begin{array}{l}\text { - Revision of the contents. } \\
\text { - Brainstorming in order to } \\
\text { bring out experiences and } \\
\text { foreknowledge about how } \\
\text { infection can happen. } \\
\text { - Topics discussion and } \\
\text { formalization on the } \\
\text { copybook. } \\
\text { - Listing of places and } \\
\text { things where you can } \\
\text { unconsciously gather } \\
\text { microbes by touching } \\
\text { them. }\end{array}$ \\
\hline $\begin{array}{l}\text { Fourth lesson: } \\
\text { beneficial and } \\
\text { harmful } \\
\text { microorganisms, } \\
\text { role of microbes } \\
\text { in human life, } \\
\text { how to defend } \\
\text { ourselves from } \\
\text { microbes. }\end{array}$ & $\begin{array}{l}\text { - Comparison and analysis of results gathered by } \\
\text { each group. } \\
\text { - Reworking of the initial hypothesis on the basis of } \\
\text { the new data. } \\
\text { - Reading and debating on materials about what } \\
\text { virus, bacteria and fungi can do (e.g. diseases, } \\
\text { decay, immune defence) or for what can be used } \\
\text { (e.g. pharmaceutical and food industry, treatment } \\
\text { of waste water). }\end{array}$ & $\begin{array}{l}\text { - Revision of the contents. } \\
\text { - Listing the situations in } \\
\text { which washing hands is } \\
\text { necessary. } \\
\text { - Right procedure to wash } \\
\text { hands. } \\
\text { - Watching cartoon that } \\
\text { explains how microbes } \\
\text { work into the mouth and } \\
\text { on the teeth. }\end{array}$ \\
\hline $\begin{array}{l}\text { Fifth lesson: } \\
\text { diseases } \\
\text { transmission, } \\
\text { immune system } \\
\text { and prevention } \\
\text { strategies. }\end{array}$ & $\begin{array}{l}\text { - Listing of defence strategies that can be adopted } \\
\text { by everyone on the basis of pupils' personal } \\
\text { experiences and of new information acquired } \\
\text { during the previous lessons. } \\
\text { - Reading, debating and drawing by using materials } \\
\text { about the different systems that the body uses to } \\
\text { defend itself (skin, tears, phagocytes, specific white } \\
\text { blood cells). }\end{array}$ & $\begin{array}{l}\text { - Revision of the contents. } \\
\text { - Group debate in order to } \\
\text { bring out foreknowledge } \\
\text { about how the body can } \\
\text { defend itself. } \\
\text { - Watching cartoon } \\
\text { explaining the immune }\end{array}$ \\
\hline
\end{tabular}




\begin{tabular}{||l||l||l||}
\hline \hline & $\begin{array}{l}\text { - Game aimed at playing the immune system, the } \\
\text { vaccines and the antibiotics functioning by using } \\
\text { flashcards (Fig. 2). }\end{array}$ & $\begin{array}{l}\text { system functioning. } \\
\text { - Reading and writing } \\
\text { about body barriers } \\
\text { against microbes, vaccine } \\
\text { - Formalization of knowledge acquired. } \\
\text { - Role playing aimed at understanding how easily a } \\
\text { disease can spread and what happens when a few } \\
\text { or, on the contrary, a lot of people are vaccinated. }\end{array}$ \\
\hline
\end{tabular}

The second column of the Table 2 contains the activities of the control group held by the tenured teacher. As regards the contents, they are not exactly corresponding in the two classes because of the different approach used and the variety in the pupils' way of learning.
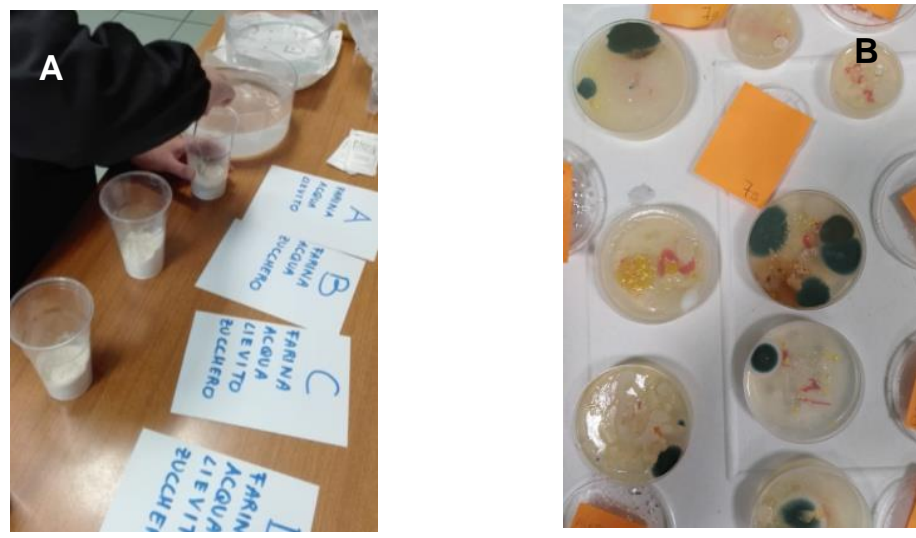

Figure 1. Experimental activities undertaken by using the scientific method.
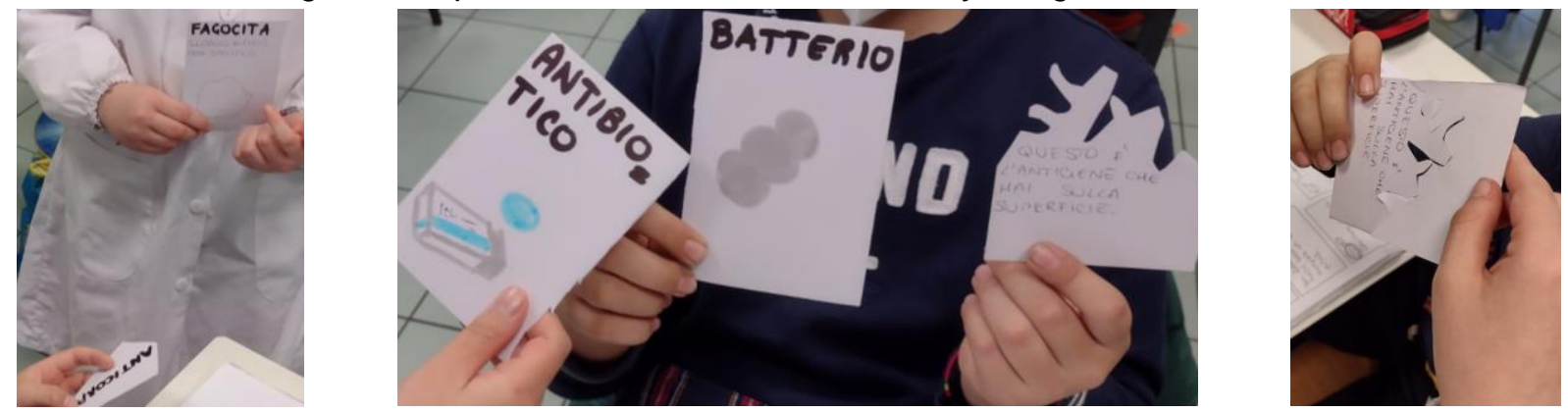

Figure 2. Understanding the functioning of the immune system, of vaccines and of antibiotics by playing.

\subsection{Assessment}

The evaluation system, aimed at sustaining the learning process, consists of three different point of view: teacher evaluating pupils, pupils evaluating both themselves and the learning path, pupils evaluating their peers. The trifocal perspective, implemented on the basis of ex-ante, ongoing and final results, is fundamental to value the progress made by each single student with different needs, characteristics and ways to demonstrate the learning. In this research, we most focused on: initial and final tests in order to compare the results of the two groups trying to use as objective as possible criteria; ongoing observation and self-evaluation with the aim of giving a more complete explanation of outcomes and collecting data about interest, participation, inclusion and fun.

The final test and the self-evaluation, similarly to the initial questionnaire, consisted of structured (multiple choice, satisfaction scales, true and false, cloze) and easy unstructured questions. The questions referred to the studied topics (microorganisms, virus, bacteria, fungi, diseases caused by microbes, infection transmission, vaccines, antibiotics and immune system), to interest in Science and microorganisms and to opinions about activities (difficulties and fun) (Galliani, 2015; Castoldi, 2016).

\section{RESULTS AND DISCUSSION}

First of all, the online survey results were analysed. Teachers and parents' answers shown a positive attitude towards the proposed topics or towards active and laboratory approaches. However, many of them believed 
that such contents are dangerous, not suitable for children and cause of anxiety. Furthermore, several teachers felt themselves not able to teach such topics or thought to necessarily need specific tools. We can say that the undertaken activities had, as secondary benefit, the opportunity to demonstrate, to parents and teachers, that Microbiology can be part of primary school curricula even without specific devices or competences.

According to outcomes, the topic lends itself to both a frontal and a laboratory approach. The learning path is confirmed to be feasible at third grade even without scientific and information technologies, in a learning environment characterized by limited space and by restrictive rules due to the pandemic emergency which limited the possibility of action.

Many studies reveal the importance of using and interchanging different approaches and methodologies when teaching biology (Gaiotto et al., 2013, 2020; Tonon et al., 2013, 2020; Pavan and Santovito, 2014; Zandonella Necca et al., 2014, 2021; Toninato and Santovito, 2015; Trevisan and Santovito, 2015; Gaiotto and Santovito, 2016; Rossi and Santovito, 2016; Capparotto et al., 2017; Favaron et al., 2017; Lago et al., 2017; Meneghetti et al., 2017; Barbacovi et al., 2018; Fassinato et al., 2018; Forlin et al., 2018; Grando et al., 2018a, 2018b; Tura et al., 2018; Chiesa et al., 2019; Gallina et al., 2019; Lui et al., 2019; Palmieri et al., 2019; Bortolami et a., 2020; Corbolino et al., 2020; Fabris et al., 2020; Zanata and Santovito, 2020; Barana et al., 2021; Bassi et al., 2021; Bertoncello et al., 2021; Frigerio et al., 2021; Furlan et al., 2021; Furlanetto et al., 2021; Pavan et al., 2021). As regards the effectiveness of the laboratory approach:

- The results of the experimental group referred to knowledge, were higher than the control group but the difference was really subtle. What we expected was a better and more significant performance of the experimental group. However, outcomes could have been affected by the presence of several students with relevant linguistic difficulties which hindered the performance. Furthermore, the control group superficially studied the immune system and the time spent to review and repeat contents was more than in the experimental group. The experimental group studied more complex and detailed topics referred to the immune system, repeating contents less times and having more fun and involvement.

- Analysing the specific items, the interest towards Science turned out to be unchanged among the control group whereas it raised among the experimental group. Moreover, the interest towards microorganisms registered a decrease in the control group and a rise in the experimental one. Even in this case, differences were not too big but they, however, pointed out a turnaround. This outcome could be sustained by further data gathered with the ongoing observations and the pupils' opinions on activities.

- Data collected with ongoing observations, self-evaluation items and opinion on activities items, also supported the effectiveness of the proposed activities on inclusion and participation of students in situation of disability or with cognitive and linguistic difficulties. Furthermore, data can sustain the hypothesis that the undertaken path could have positive effects on the pleasure in learning and on limiting negative emotions linked to the topic (e.g. anxiety, fear or concern).

Besides, the obtained outcomes can also answer to the doubts that came out with the online survey administered to teachers and parents. Many of them worried about the possibility of the topics to not be understood by young learners or to be source of fear. Others thought that some activities could be dangerous or hard to be developed without specific and expensive tools.

The sample was limited from a statistic point of view and, moreover, as part of a didactic research many factors can influence the outcomes. Therefore, the sample would need to be widen. Nevertheless, it was a further way to sustain, not only the feasibility of a topic traditionally not included in teaching curricula, but also the effectiveness of the laboratory and playful approach.

\section{REFERENCE LIST}

Barana, C., Dall'Acqua d'Industria, L., Bellio, M., Corrà, F., Bonato, M., Schumann, S., Irato, P. \& Santovito, G. (2021) "Teacher, may we touch it?" An innovative laboratory approach to address macroscopic and microscopic anatomy of the digestive system of human and mammals in primary school. In: INTED2021 Proceedings, IATED, Valencia, https://doi.org/10.21125/inted.2021.0210

Barbacovi, V., Santovito, G. \& Irato, P. (2018) Little scientists for large discoveries: an experimental 
approach to survey the world with classes ii of the primary school - The observation and study of plant life. In: EDULEARN18 Proceedings, IATED, Valencia. https://doi.org/10.21125/edulearn.2018.1579

Bassi, C., Fattori, G., Bellio, M., Corrà, F., Bonato, M., Schumann, S., Irato, P. \& Santovito, G. (2021) Feel with the skin. A didactic research to introduce the integumentary system and sensory perception in primary school. In: EDULEARN21 Proceedings, IATED, Valencia. https://doi.org/10.21125/edulearn.2021.1352

Bertoncello, O., De Rosso, A. \& Santovito, G. (2021) My classroom as big as the world of CAITPR. An innovative educational-didactic approach for the training of eco-sensitive citizens. In: EDULEARN21 Proceedings, IATED, Valencia. https://doi.org/10.21125/edulearn.2021.0372

Bortolami, I., Bisaccia, P., Corrà, F., Bonato, M., Irato, P. \& Santovito, G. (2020) The blue gold: an empirical research to introduce the discussion of water issue in relation to plants, animals and human in primary school. In: EDULEARN20 Proceedings, IATED, Valencia, https://doi.org/10.21125/edulearn.2020.0496.

Capparotto, A., Bramuzzo, S., Callegaro, E., Poloni, E., Corrà, F. \& Santovito G. (2017) The didactics of biology in primary school: an innovative approach to skeletal system teaching in fifth class based on comparative vertebrate anatomy. In: INTED2017 Proceedings, IATED, Valencia. http://doi.org/10.21125/inted.2017.0935

CAST (2011) Universal design for learning guidelines version 2.0. Wakefield.

Castoldi, M. (2016) Valutare e certificare le competenze. Carocci editore, Roma.

Chiesa, E., Irato, P. \& Santovito, G. (2019) The circulatory system of vertebrates and invertebrates: an empirical research to introduce in the fourth class the treatment of animal morphology in a comparative key. In: INTED2019 Proceedings, IATED, Valencia. https://doi.org/10.21125/inted.2019.0391

Corbolino, N., Bisaccia, P., Corrà, F., Bonato, M., Irato, P. \& Santovito, G. (2020) The vegetable garden. an instrument for sustainable development education and care pedagogy. In: INTED2020 Proceedings, IATED, Valencia, https://doi.org/10.21125/inted.2020.1282.

Curtis, H. \& Barnes, N. S. (2009) Invito alla biologia. Zanichelli, Bologna.

Danesi, B. (2006) L'insegnamento della Biologia..In: Pianeta Galileo. Firenze.

Davies, N. \& Sutton, E. (2015) Tiny. The Invisible World of Microbes. Walker Books, London.

Fabris, G., Bisaccia, P., Corrà, F., Bonato, M., Irato, P. \& Santovito, G. (2020) Discovering the nervous system. An innovative teaching approach for primary school. In: EDULEARN20 Proceedings, IATED, Valencia, https://doi.org/10.21125/edulearn.2020.0889.

Fassinato, C., Nicorelli, E., Corrà, F., Irato, P., Guidolin, L. \& Santovito G. (2018) An innovative approach to deal with biodiversity at school with its investigation in different environments. In: EDULEARN18 Proceedings, IATED, Valencia. https://doi.org/10.21125/edulearn.2018.0717

Favaron, A., Ancona, E., Bramuzzo, S., Callegaro, E., Guidolin, L., Irato, P. \& Santovito, G. (2017) An innovative teaching approach to circulatory and skeletal systems based on comparative vertebrate anatomy and physiology. In: EDULEARN17 Proceedings, IATED, Valencia. http://doi.org/10.21125/edulearn.2017.1015

Forlin, E., Santovito, G., Guidolin, L. \& Irato, P. (2018) Citrus fruits. Course to educate to scientific curiosity. In: EDULEARN18 Proceedings, IATED, Valencia. https://doi.org/10.21125/edulearn.2018.1573

Frigerio, R., Bellio, M., Bonato, M., Santovito, G. \& Irato, P. (2021) Fruit and vegetables: discovering conscious food choices. Creation of an educational project to stimulate the study of science in a class ii of a lower secondary school. In: EDULEARN21 Proceedings, IATED, Valencia. https://doi.org/10.21125/edulearn.2021.1329

Furlan S., Bellio M., Corrà F., Bonato M., Schumann S., Irato P., Tamino G., Santovito G. (2021) A, B, C, D... NA: Genetics explained to children. an innovative didactic and laboratory proposal in primary school. In: EDULEARN21 Proceedings, IATED, Valencia. https://doi.org/10.21125/edulearn.2021.1216

Furlanetto, L., Bellio, M., Corrà, F., Bonato, M., Schumann, S., Irato, P. \& Santovito G. (2021) The circle of 
life. Human reproduction and embryonic development in primary school. In: INTED2021 Proceedings, IATED, Valencia, https://doi.org/10.21125/inted.2021.0209

Gainotti, A. \& Modelli, A. (2008) Scienze della natura. Zanichelli, Bologna.

Gaiotto, A., Tonon, S. \& Santovito, G. (2013) The scientific method in the teaching of life sciences in primary school, The plants and their seasonal changes". In EDULEARN13 Proceedings, pp. 4226-4235.

Gaiotto, A. \& Santovito G. (2016) An innovative didactic approach to the study of invertebrate animals in primary school. In: EDULEARN16 Proceedings, IATED, Valencia. http://doi.org/10.21125/edulearn.2016.1284

Gaiotto, A., Bisaccia, P., Bonato, M., Irato, P., Corrà, F. \& Santovito, G. (2020) The plants and their seasonal changes: teaching biology in primary school using the scientific method. In: INTCESS2020 Proceedings, OCERINT, Istanbul, pp 261-270.

Galliani, L. (2015) L'agire valutativo. La Scuola, Brescia.

Gallina, S., Irato, P. \& Santovito, G. (2019) Inquiry into animal tracks: an experimental application of IBSE inquiry based science education- approach in the ecological field in primary school. In: INTED2019 Proceedings, IATED, Valencia. https://doi.org/10.21125/inted.2019.0089

Grando, G., Bramuzzo, S., Irato, P., Guidolin, L., Ferrari, L. \& Santovito, G. (2018) Introduction to the world of insects: a didactic research in kindergarten. In: INTED2018 Proceedings, IATED, Valencia. https://doi.org/10.21125/inted.2018.1066

Grando, G, Bramuzzo, S., Callegaro, E., Guidolin, L., Irato, P. \& Santovito, G. (2018) Who is afraid of insects? A didactic research in the biological field in kindergarten. In: EDULEARN18 Proceedings, IATED, Valencia. https://doi.org/10.21125/edulearn.2018.0724

Kaminske, A. N., Kuepper-Tetzel, C. E., Nebel, C. L., Sumeracki, M. A. \& Ryan, S. P. (2020) Transfer: A Review for Biology and the Life Science. CBE Life Sciences Education, 19 (3).

Lago, A., Masiero, S., Bramuzzo, S., Callegaro, E., Poloni, E., Corrà, F. \& Santovito G. (2017) Exploring microbiology and biotechnologies: a laboratory approach to the study of yeasts and bacteria in primary school. In: INTED2017 Proceedings, IATED, Valencia. http://doi.org/10.21125/inted.2017.0992

Longo, C. (1998). Didattica della biologia. La Nuova Italia Editrice, Firenze.

Lui, F., Irato, P. \& Santovito, G. (2019) Discovering living organisms: a didactic research to introduce biology in kindergarten. In: EDULEARN19 Proceedings, IATED, Valencia. https://doi.org/10.21125/edulearn.2019.1040

Mayr, E. (1982) The growth of biological thought. Diversity, evolution and inheritance. Belknap Press, Cambridge.

Meneghetti, G, Bramuzzo, S., Callegaro, E., Guidolin, L., Irato, P. \& Santovito G. (2017) The kingdom of fungi in primary school: an educational research in biology field. In: EDULEARN17 Proceedings, IATED, Valencia. https://doi.org/10.21125/edulearn.2017.1023

Merkel, S. M. (2016) American Society for Microbiology resources in support of an evidence-based approach to teaching microbiology. FEMS Microbiology Letters, 363.

Messina, L. \& De Rossi, M. (2015) Tecnologie, formazione e didattica. Carocci, Roma.

Minelle, C., Rocca, L. \& Bussi, F. (2016) Storia e geografia. Idee per una didattica congiunta. Carocci, Roma.

MIUR (2012) Indicazioni Nazionali per l'infanzia e il primo ciclo di istruzione. Roma.

MIUR (2018) Indicazioni Nazionali e Nuovi Scenari. Roma.

Nigris, E. (2005) Didattica generale, Edizioni Angelo Guerini e Associati SpA, Milano.

Nistor, A., Gras-Velazquez, A., Billon, N. \& Mihai, G. (2018) Science, Technology, Engineering and Mathematics Education Practices in Europe. Scientix Observatory report. European Schoolnet, Brussels.

ONU (2015) Trasformare il nostro mondo: l'Agenda 2030 per lo Sviluppo. New York. 
Padoa Schioppa, E. (2014) Metodi e strumenti per l'insegnamento e l'apprendimento della biologia. Edises, Napoli.

Palmieri, G., Irato, P., Nicolosi, P. \& Santovito, G. (2019) A day at the museum. Laboratory teaching in the Museum of Zoology at the University of Padua for primary school. In: EDULEARN19 Proceedings, IATED, Valencia. https://doi.org/10.21125/edulearn.2019.1037

Pavan, C. \& Santovito, G. (2014) The laboratory didactics in the teaching -learning processes of life sciences. an educational project on microorganisms in the alimentation in primary school. In: EDULEARN14 Proceedings, IATED, Valencia, pp 7546-7555.

Pavan, C., Bellio, M., Corrà, F., Bonato, M., Schumann, S., Irato, P. \& Santovito, G. (2021) Microorganisms in the alimentation in primary school: the laboratory didactics in the teaching - learning processes of life sciences. In: INTCESS2021 Proceedings, OCERINT, Istanbul. https://doi.org/10.51508/intcess.202176

Pluviano, S. \& Della Sala, S. (2020) II Pregiudizio di Conferma. Available: https://www.cicap.org/n/articolo.php?id=279298.

Pontecorvo, C., Ajello, A. M. \& Zucchermaglio, C. (2004) Discutendo si impara. Interazione e conoscenza a scuola. Carocci, Roma.

Public Health England (2020) e-Bug. Available: https://www.e-bug.eu/ .

Rossi, E. \& Santovito, G. (2016) Introduction to Mendelian genetics in primary school. In EDULEARN16 Proceedings, IATED, Valencia. http://doi.org/10.21125/edulearn.2016.1274

Santovito, G. (2015) Insegnare la biologia ai bambini. Dalla scuola dell'infanzia al primo ciclo d'istruzione. Carocci, Roma.

Semeraro, R. (2009) La progettazione didattica. Upsel Domeneghini Editore, Padova.

Sheldrake, M. (2020) L'ordine nascosto: la vita segreta dei funghi. Marsilio Editori, Venezia.

Strategic Advisory Group of Experts on Immunization (2014) Report of the sage working group on vaccine hesitancy.

Tomlinson, C. A. (2006) Adempiere la promessa di una classe differenziata, LAS, Roma.

Toninato, V. \& Santovito, G. (2015) The laboratory didactics in the teaching-learning processes of life sciences. an educational project on the structure of the flower and the inflorescences phenomenon in primary school. In: EDULEARN15 Proceedings, IATED, Valencia, pp 2245-2254.

Tonon, S., Gaiotto, A. \& Santovito, G. (2013) The active teaching of life sciences in primary school: a comparative approach to the musculoskeletal system. In: EDULEARN13 Proceedings, IATED, Valencia, pp. 4289-4298.

Tonon, S., Bisaccia, P., Bonato, M., Irato, P., Corrà, F. \& Santovito, G. (2020) A comparative approach to the musculoskeletal system in primary school. In: INTCESS2020 Proceedings, OCERINT, Istanbul, pp 251-260.

Tortora, G. J., Funke, B. R. \& Case, C. L. (2008) Elementi di Microbiologia. Pearson Paravia Bruno Mondadori S.p.A., Firenze.

Trevisan, T. \& Santovito, G. (2015) Teaching evolution: a laboratory approach. In: EDULEARN15 Proceedings, IATED, Valencia, pp 2234-2244.

Tura, N., Guidolin, L., Irato, P. \& Santovito, G. (2018) From cell to inheritance of characters: an introduction to classical genetics in primary school. In: INTED2018 Proceedings, IATED, Valencia. https://doi.org/10.21125/inted.2018.1076

Vygotskij, L. S.(1934) Pensiero e linguaggio, Laterza.

Wiggins G. e J. Mc Thighe, Fare progettazione. La "teoria" di un percorso didattico per la comprensione significativa, Roma: LAS, 2004.

Zanata, M. \& Santovito, G. (2020) The "Da Vinci" Biodiversity Park (Treviso, Italy). A didactic garden as innovative support to the teaching of science in secondary school. In: INTED2020 Proceedings, IATED, Valencia, https://doi.org/10.21125/inted.2020.1474. 
Proceedings of INTCESS 2022-9th International Conference on Education \& Education of Social Sciences 17-18 January 2022- Online Conference

Zandonella Necca, I., Bellio, M., Corrà, F., Bonato, M., Schumann, S., Irato, P., Tamino, G. \& Santovito, G. (2021) Sustainable food: an innovative approach based on the assessment for learning method in secondary schools. In: INTCESS2021 Proceedings, OCERINT, Istanbul, https://doi.org/10.51508/intcess.202177

Zandonella Necca, I., Tamino, G. \& Santovito, G. (2014) Sustainable food: an educational proposal, for key stage 3 in secondary schools, based on the assessment for learning method. In: EDULEARN14 Proceedings, IATED, Valencia, pp 7348-7356. 